\title{
Research on Humanities Education of Higher Vocational English Education
}

\author{
Zhihong Fan, Yunyan Tao
}

Jiangxi University of Engineering, Xinyu, Jiangxi, 338000

Keywords: humanities education; higher vocational English; social development

\begin{abstract}
With the development of global economy, the relationship between English education and humanity quality education has become more and more close. The purpose of English education is not only to improve students' language ability, but also to improve students' humanistic qualities. The improvement of humanistic quality will enhance the subjective learning initiative of students. The two complement each other in student education, which helps to promote the overall development of students and meets the needs of talents in contemporary society.
\end{abstract}

\section{Introduction}

Higher vocational education aims to cultivate skilled talents and promote the harmonious development of people and society. As an important part of higher vocational education, college English education also carries the important task of guiding students to pursue their own development, inherit culture, and strengthen cultural exchanges between China and foreign countries. It is a hotbed of cultural education and personality shaping that breeds qualified talents in society. Humanities quality teaching plays a vital role in the development of society, especially in the teaching of higher vocational education.

\section{The Status of Humanities and the Status Quo of Higher Vocational English Education}

With the changes of society, higher vocational education schools are growing rapidly, and higher vocational English teaching is gradually expanding with its unique teaching mode and teaching objectives. Higher vocational colleges train high-skilled talents for the society. Its teaching mode and teaching objectives must meet the needs of society. The teaching goal of English in higher vocational colleges is to train professional skills and applied talents for the society. However, as far as the English teaching in higher vocational colleges is concerned, it does not reflect its professional training objectives. This is because people have long lacked a correct understanding of the nature of higher vocational education. From the perspective of the student's main body, students who enter colleges and universities generally have a large sense of loss. Students can't recognize the value of higher vocational education emotionally. According to the students' own cultural level, the cultural foundation of higher vocational college students is far from the undergraduate students. This also gives English teaching to higher vocational colleges. Brought great difficulties. Most of the current higher vocational colleges have problems such as the lack of teachers, the younger age structure of teachers, and the low academic qualifications of teachers. In terms of teaching modes and methods, teachers generally follow the old traditional teaching methods, and their teaching methods are relatively simple, which cannot meet the needs of social and technological development and the needs of different talents. In order to change this situation, we must pay attention to the humanistic quality education of students, broaden the horizons of students by teaching students other than textbooks, and increase the subjective initiative of students' learning, and stimulate their interest in the culture of another country. The desire for language. On the other hand, if students are interested in foreign languages, they will increasingly want to acquire foreign cultural customs other than books. Therefore, humanistic quality education and English education in higher vocational schools are inseparable and mutually reinforcing. 


\section{Principles of Humanities Education in Higher Vocational English Education}

Objectively analyze the content of humanities education contained in teaching materials to achieve students' rational grasp of humanities education content in teaching materials. Because we and people in English-speaking countries live in different cultural backgrounds, there are great differences in customs, religious beliefs, moral values, and values. In the process of English learning, English learners will undoubtedly face the cultural shock of English culture. English educators should consciously educate students to face up to and rationally accommodate these differences, and have an objective understanding and rational grasp. The language of each nation bears the essence of the culture of the nation. The purpose of any form of education is to promote the good side of human nature and to blame the ugly side of human nature. Humanities education aims to teach people to be good, to be evil, to love life, to cherish life. Therefore, we should make full use of the content of teaching materials to praise the virtues of human nature, educate students to correctly understand the world, society and life, and have a healthy and positive attitude towards life, a tenacious will and a scientific and rational ability to solve problems.

Language is the carrier of culture and a tool for communication. The purpose of learning English is to achieve cross-cultural communication. By learning English, people can share the splendid culture shared by mankind, enhance mutual understanding and mutual trust, promote world peace and development, and help us learn to absorb foreign advanced science and technology and progressive culture. However, foreign languages are by no means a tool for "cultivating foreigners and foreigners" and spreading "the philosophy of foreign slaves." Foreign language educators should always take the responsibility of carrying forward national culture and national spirit as their own responsibility. By virtue of their own learning, they use various methods to expose the ugly phenomenon of Western society and promote the traditional virtues of the Chinese nation in a timely and appropriate manner. Promote national self-confidence and national pride.

\section{Specific Ways of Developing Humanities Quality Education in Higher Vocational English Education}

From leadership decision-making to school-running thinking, we must pay full attention to the input of humanistic education and the cultivation of students' humanities quality, vigorously promote the development of humanities and social sciences in society and schools, and actively promote scientific spirit and humanistic spirit in vocational English education. The harmony, highlighting the leading role of the humanistic spirit in science and technology. On the basis of the existing teaching equipment, the humanistic spirit of the technical education itself and the newly opened humanities curriculum will be tapped to build a campus humanistic environment, change and guide students' attitude towards humanistic quality education and rationally construct the humanistic spiritual foundation, for example, for higher vocational education. The development of English curriculum for college aesthetics can be combined with the introduction of aesthetics and the cultivation of students' aesthetic concepts. Using the experience of students, we can further create the humanistic environment of the school, the traditional newspapers of the school, the publicity window and the network, in addition to completing the propaganda mission. In addition, they can be built into positions of aesthetic appreciation.

Exploring and summarizing the scientific and operable humanistic quality evaluation standards are not guided by the test, not based on memory and standard answers, and the new evaluation criteria of quality improvement, can establish a guiding role for students in the humanities quality education. Different from science education, it emphasizes objectivity, but should combine the characteristics of each student, corrective training in a targeted manner, combine the promotion of quality education with the construction of campus humanities environment, the curriculum can be more free, the lectures are more abundant, and the students are During the school period, a certain amount of lectures and lectures should be completed, and some of the lectures should be completed. The teacher will arrange a certain amount of humanities and English subjects for the students to 
study and summarize. These do not require the use of class time, but the teacher's correction of the student's research summary must be Be serious and responsible, and eventually form a humanistic quality assessment report. After a number of practices, accumulating experience, and striving to make the humanities quality assessment report have a higher degree of credibility, it can provide a certain reference for the value of human English in higher vocational education.

Advocate to grasp students in the form of "people" and understand students. Taking "the development of students is the purpose" as the highest principle and starting point, it reflects the respect of students' free will and respects the needs and emotions of students. Therefore, higher vocational English educators should truly establish the awareness of the subjective status of the educated in the mind and respect the needs and personality of the educated. The entire educational environment must be designed according to the needs of students. Whether it is educational content, teaching methods, teacher-student relationship, or educational evaluation, it should consciously infiltrate a sense of respect and care. The requirements of English teaching must be based on the needs of students, higher than the existing level of students and can be achieved through the efforts of students, which is conducive to the development of students; teaching design must be beneficial to the awakening, excavation and promotion of students' potential, and promote students' autonomy. Development; the form of teaching must focus on the overall growth of students, promote the harmonious development of students' cognition, emotions and skills, and pay attention to the sustainable development of students. Language teaching should be the most typical emotional education and humanistic education. Its mission is to let students feel the context, experience the sense of language, and guide imagination and creativity. Higher vocational English educators must carefully organize and design teaching forms, and create real-life scenarios based on different teaching contents, different educational objects, different teaching environments and conditions, and encourage students to apply language in specific contexts. To discuss and solve problems, students use middle school, use in school, use language to do things in real communication, achieve the effect of using tasks to promote the communication of English teaching, and reflect the humanistic care of English subjects. Teachers and students communicate and learn in an equal way, allowing students to take the initiative and initiative in a relaxed and pleasant atmosphere, which is conducive to the development of individuality and the cultivation of creativity. In short, humanistic value education is not only about the students' innovative quality and professionalism, but also about the sustainable development and rejuvenation of the nation.

Humanities education must rely on specific teaching content and teaching situations. Therefore, teachers should fully explore the humanities education resources contained in them according to the teaching materials, and infiltrate humanities knowledge into students with purpose and method. When you study an article, you should learn more about the background of writing and related history, geography, culture, politics, customs, etc., so that students can understand the cultural connotation of the language they learn while learning the language. Teachers must dare to innovate, try a variety of teaching methods in combination with the characteristics of the students they teach, and activate the classroom atmosphere to make the teaching materials more ideological, intellectual and interesting. Through discussion, analysis, comparison and other series of classroom activities, they will participate in it, explore the fun of language learning, increase their subjective initiative, and achieve diversified teaching methods, so that students can master the learning methods and humanities in a limited classroom. Literacy, cultural taste and even the entire spiritual world have been improved. Teachers as the guide and implementer of education, the teacher's educational concept and humanistic quality directly affect the teaching effect. Therefore, teachers must update their educational concepts and constantly enrich their own humanistic quality education. Humanities education is a very abstract concept. It involves a wide range of content, from small people to the world, so the teachers, as the main body of education, must constantly enrich their knowledge and culture, and must also be involved in amateur life. A wide range of humanities knowledge, only rich in human knowledge, can apply humanities education to the practical teaching process, infiltrate the students bit by bit, and do the words and deeds so that students can have fun and satisfy in the process of humanities education. And pride. To this end, college English teachers 
should constantly improve their own quality, infect students with profound knowledge and positive optimism, so that they form an optimistic attitude towards life and a positive psychological quality.

\section{Conclusion}

An excellent teacher should learn to teach students in accordance with their aptitude and adopt a variety of teaching methods and means to enhance students' subjective initiative. The classroom teaching mode should be transformed from infusion to experiential and development, namely, self-learning, inquiry learning, and cooperative learning. The purpose of education is not only to teach students knowledge, but also to pay attention to the cultivation of students' learning ability, so that students can develop a correct learning attitude at all stages of life, and constantly enrich their humanities and enjoy learning.

\section{Acknowledgements}

Project Fund: Research Project of Teaching Reform in Higher Education Institutions in Jiangxi Province "Research on the Importance of Humanities Education in Higher Vocational English Teaching" (JXJG-17-28-2)

\section{References}

[1] Dong Yingxi. The status quo of English education in higher vocational colleges and the training strategy of English application ability [J]. China Science and Education Innovation Guide, 2012 (2).

[2] Zhang Hongbin. Research on Humanity and Quality Education in Chinese High Schools [D]. Dalian Maritime University, 2012.

[3] Li Bing, Li Gang. Humanities Quality Education in English Teaching in Higher Vocational Colleges [J]. Journal of Xianning University, 2010(7).

[4] Wang Xi. Research on the Innovation of Humanities Quality Education in College English Teaching [J]. China Science and Technology Information, 2011 (7).

[5] Zhao Yiyu. Infiltration of humanities quality education in college English teaching [J]. Journal of Linguistics, 2012 (11). 